\title{
Bankruptcy Law and The Cost of Credit: The Impact of Cramdown on Mortgage Interest Rates
}

\section{Citation}

Goodman, Joshua, and Adam Levitin. 2012. Bankruptcy Law and The Cost of Credit: The Impact of Cramdown on Mortgage Interest Rates. HKS Faculty Research Working Paper Series RWP12-037, John F. Kennedy School of Government, Harvard University.

\section{Published Version}

http://web.hks.harvard.edu/publications/workingpapers/citation.aspx?Publd=8513

\section{Permanent link}

http://nrs.harvard.edu/urn-3:HUL.InstRepos:9403179

\section{Terms of Use}

This article was downloaded from Harvard University's DASH repository, and is made available under the terms and conditions applicable to Other Posted Material, as set forth at http:// nrs.harvard.edu/urn-3:HUL.InstRepos:dash.current.terms-of-use\#LAA

\section{Share Your Story}

The Harvard community has made this article openly available.

Please share how this access benefits you. Submit a story.

Accessibility 


\section{Bankruptcy Law and The Cost of Credit: The Impact of Cramdown on Mortgage Interest Rates Faculty Research Working Paper Series}

\section{Joshua Goodman}

Harvard Kennedy School

\section{Adam Levitin}

Harvard Law School

\section{August 2012 RWP12-037}

Visit the HKS Faculty Research Working Paper series at:

http://web.hks.harvard.edu/publications

The views expressed in the HKS Faculty Research Working Paper Series are those of the author(s) and do not necessarily reflect those of the John F. Kennedy School of Government or of Harvard University. Faculty Research Working Papers have not undergone formal review and approval. Such papers are included in this series to elicit feedback and to encourage debate on important public policy challenges. Copyright belongs to the author(s). Papers may be downloaded for personal use only. 


\title{
Bankruptcy Law and The Cost of Credit: The Impact of Cramdown on Mortgage Interest Rates*
}

\author{
Joshua Goodman \\ Harvard University \\ Joshua_Goodman@hks.harvard.edu \\ Adam Levitin \\ Harvard University \\ alevitin@law.harvard.edu
}

August 8, 2012

\begin{abstract}
The role of bankruptcy law in credit markets has received renewed attention in the aftermath of the housing bubble collapse. The fundamental challenge for research on this topic is to separate the impact of legal factors from other features of the credit environment. We do so by exploiting historical variation in federal judicial rulings regarding whether Chapter 13 bankruptcy filers could reduce the principal owed on a home loan to the home's market value. The practice, known as cramdown, was definitively prohibited by the Supreme Court in 1993. We find evidence that home loans closed during the time when cramdown was allowed had interest rates 10-20 basis points higher than loans closed in the same state when cramdown was not allowed, which translates to a roughly 1-2 percent increase in monthly payments. Consistent with the theory that lenders are pricing in the risk of principal modification, interest rate increases are higher for the riskiest borrowers and zero for the least risky, as well as higher in states where Chapter 13 filing is more common. Though the price of credit rises slightly, we find no evidence of a change in the quantity of credit provided. The relatively small impacts of cramdown on the cost of credit suggests that the insurance benefits of bankruptcy may be relatively inexpensive.
\end{abstract}

${ }^{*}$ We thank for helpful comments Edward Glaeser, Edward Morrison, and participants at the Conference on Empirical Legal Studies. Institutional support from the Harvard Kennedy School's Taubman Center for State and Local Government is gratefully acknowledged. Any errors are our own. 


\section{Introduction}

The bursting of the housing bubble has left millions of American homeowners underwater on their mortgages. Estimates from the last quarter of 2011 suggest that over eleven million households, or nearly a quarter of mortgagors, are underwater, with many owing more than $150 \%$ of the value of their property $\left.\right|^{1}$ The more than $\$ 700$ billion in negative equity has been cited as a critical factor contributing to foreclosures, preventing the housing market from clearing, and delaying macroeconomic recovery by impeding consumer spending (Mayer et al. 2009, Case et al. 2011. Dynan 2012).

Despite general recognition of the problems created by negative equity, there has been little in the way of voluntary principal reduction by lenders or mortgage servicers. The largest mortgagees in the country, Fannie Mae and Freddie Mac, prohibit principal reduction outright. Portfolio lenders are often reluctant to write-down principal because of the loss recognition consequences. Third-party servicers are sometimes contractually prohibited from modification and are often incentivized to foreclose or undertake other types of modifications (Gelpern and Levitin 2009. Levitin and Twomey 2011). Government action has tried to encourage principal reduction with limited success. The federal government's Home Affordable Modification Program includes a Principal Reduction Alternative that pays servicers up to 21 cents for every dollar of mortgage debt they forgive. The landmark federal-state mortgage servicing fraud settlement announced in February 2012 calls for at least $\$ 10$ billion in principal reductions. These developments, however, have been modest in scale relative to the scope of negative equity nationwide.

During the early years of the housing crisis, recognition of the various frictions that impede loan modification, and in particular principal reduction, led to proposals to permit mortgages to be modified in personal bankruptcy proceedings without the consent of the mortgagee (Levitin 2009). Involuntary modification of mortgages in bankruptcy was designed to cut through transactional frictions, as well as to encourage voluntary modifications outside of bankruptcy. These proposals, known as "cramdown" or "stripdown" would have resulted in the underwater portion

\footnotetext{
${ }^{1}$ See the March 1, 2012 press release from CoreLogic entitled, “CoreLogic Reports Negative Equity Increase in Q4", available from the authors or at http://www.corelogic.com/about-us/news/asset_upload_file909_ $14436 \cdot \mathrm{pdf}$.
} 
of mortgage loans being treated as unsecured loans in bankruptcy, and therefore dischargeable by the debtor for pennies on the dollar. The cramdown proposal took the form of highly contentious legislation that passed the House of Representatives in 2008, but which failed in 2009 to achieve the requisite 60 votes for cloture in the Senate, despite the endorsement of President Obama.

Opponents of this legislation argued that it would substantially increase the cost of mortgage credit going forward. The Mortgage Bankers Association, which led the lobbying against the legislation, contended that cramdown would result in a 150 or 200 basis point increase in the average cost of mortgages ${ }^{2}$ The authors of that study admitted, however, that "The number is an approximation, as there is no market parallel from which we can make exact comparisons." In other words, at that point, no rigorous empirical evidence existed with which to forecast the impact of cramdown legislation on credit markets.

In this paper, we provide the first such evidence, using a natural experiment to test the impact of bankruptcy cramdown on mortgage interest rates. Between 1978 and 1993, a number of bankruptcy, district and circuit courts throughout the United States issued varying opinions on the permissibility of mortgage cramdown under federal bankruptcy law. In 1993, the Supreme Court declared the practice impermissible under the law, citing in part legislative history suggesting concern about the impact of cramdown on the cost of credit. The legal variation between judicial districts and over time allows us to test cramdown's impact on mortgage interest rates and other characteristics using a difference-in-difference strategy.

We find evidence that home loans closed during the time when cramdown was allowed had interest rates 10-20 basis points higher than loans closed in the same state when cramdown was not allowed, which translates to a roughly 1-2 percent increase in monthly payments. Consistent with the theory that lenders are pricing in the risk of principal modification, interest rate increases are higher for the riskiest borrowers and zero for the least risky, as well as higher in states where Chapter 13 filing is more common. Though the price of credit rises slightly, we find no evidence of a change in the quantity of credit provided. The relatively small impacts of cramdown on the

\footnotetext{
${ }^{2}$ See the December 16, 2008 letter from the Mortgage Bankers Association to Senator Richard Durbin available from the authors or at http://www.mortgagebankers.org/files/Advocacy/2008/ MBAAnswersSenatorDurbinsquestiononBankruptcy.pdf The MBA's impact claim and analysis changed over time (Levitin 2009).
} 
cost of credit suggests that the insurance benefits of bankruptcy may be relatively inexpensive.

Our paper makes two major contributions. First, it provides the first clear empirical evidence about the impact of cramdown on credit markets. We are aware of nearly no prior research on this question. Using an equilibrium model of consumer default, Luzzetti and Neumuller (2012) estimate little or no impact of cramdown on default rates and house prices. They do not, however, estimate the impact of cramdown on the equilibrium cost of credit, nor is it clear how sensitive their estimates are to their choices of model parameters. Fitzpatrick IV and Thomson (2010) review evidence from the 1980s farm foreclosure crisis, during which Congress enacted legislation permitting cramdown for bankruptcy filers under the newly created Chapter 12 . They cite an earlier survey of a "small group of bankers", who reported little change in the interest rates they were granting to farmers. Such self-reporting by a small sample of lenders is not particularly convincing, particularly given the difficulty of separating the impact of cramdown from the changing economic environment at that time. We believe that our paper is thus the first to provide wellidentified estimates of the impact of cramdown on the cost and quantity of credit.

Our second, more general, contribution is to the literature on the impact of bankruptcy law on credit markets, a surprisingly limited area given the centrality of credit availability and cost impact claims to policy debates over bankruptcy reform. ${ }^{3}$ The bulk of this research has focused on the impact of exemptions that protect property from creditor attachment, exploiting variation between states and over time in the maximum value of such exemptions. These studies reach conflicting conclusions about the impact of higher exemption levels on home, car and small business loans, with some finding higher interest rates and lower loan volumes (Gropp et al. 1997, Lin and White 2001. Berkowitz and White 2004) and others finding no discernible effect (Berkowitz and Hynes 1999. Chomsisengphet and Elul 2006). Relatedly, Pence (2006) finds lower home loan volumes in states with judicial foreclosure requirements that substantially slow down the foreclosure process. Our paper is the first to use judicial rulings as a source of exogenous variation in the state of bankruptcy law and is the first to show clear evidence of differential impacts of bankruptcy law by the risk to the lender of a given loan ending up in bankruptcy.

\footnotetext{
${ }^{3}$ We limit our focus here to research that engages seriously with problems of causal inference.
} 
A brief outline of our papers is as follows. In section 2, we define cramdown and discuss its legal history. In sections 3 and 4, we describe the data and empirical strategy at the heart of this paper. In section 5, we discuss our empirical results. Section 6 concludes with a discussion of the implications of these results for legal and economic policy.

\section{Cramdown}

Consumer bankruptcy comes in two main flavors, referred to by their chapter in the United States Bankruptcy Code: Chapter 7 liquidations and Chapter 13 repayment plans ${ }^{4}$ In Chapter 7, the debtor surrenders all assets, other than a limited subset of statutorily "exempt" assets, for distribution to creditors. This means that in most circumstances a Chapter 7 debtor will not be able to retain his or her home. In Chapter 13, in contrast, the debtor usually retains all of his property, but must devote all disposable personal income for the next three or five years to repaying creditors under a court-supervised repayment plan and budget. Debtors seeking to retain major property, such as a residence, typically file for Chapter 13, although there is significant geographical and racial variation in the propensity to use Chapter 13 (Braucher et al.|2012).

In a Chapter 13 bankruptcy, the debtor proposes a 3-5 year repayment plan that, if it complies with the relevant statutory requirements, will be confirmed by the court. During the plan period, creditors may not attempt to collect pre-bankruptcy debts other than through the bankruptcy process. If the debtor completes the repayment plan, then the debtor receives a discharge of unpaid pre-bankruptcy debts. If the debtor fails to complete the repayment plan, however, the bankruptcy case will be dismissed without a discharge, and creditors may then resume their collection activities.

Chapter 13 debtors have a great deal of leeway in structuring their repayment plans. A Chapter 13 debtor is able to restructure almost all types of debts, with the repayment plan able to specify changes in interest rates, amortization, and terms of loans. A Chapter 13 repayment plan may also "cram down" undersecured (or "underwater") debts, those secured by collateral worth less than the amount of the debt. Cramdown bifurcates the undersecured creditor's claim into a secured

\footnotetext{
${ }^{4}$ For an overview of bankruptcy law and recent empirical research, see White (2011).
} 
claim for the value of the collateral and a general unsecured claim for the difference between the loan amount and the collateral's value (the "deficiency"). This distinction matters because a Chapter 13 plan must pay a secured creditor the value of its secured claim, while a general unsecured claim is guaranteed only as much as would be paid out in a Chapter 7 liquidation, typically very little or nothing (Jimenez 2009). In recent years, general unsecured debt in Chapter 13 cases has traded at about 10-15 cents on the dollar (Levitin 2010). Therefore, from a lender's perspective, cramdown is equivalent to a forced principal reduction on the debt to the value of the collateral, based on a judicial rather than a market valuation. Cramdown is likely to result in a near complete loss of the underwater portion of the debt if the bankruptcy plan is completed.

While Chapter 13 permits restructuring of almost all types of debts, it explicitly excludes certain home mortgage loans. The Bankruptcy Code provides that a Chapter 13 repayment plan may "modify the rights of holders of secured claims, other than a claim secured only by a security interest in real property that is the debtor's principal residence" (11 U.S.C. $§ 1322(b)(2))$. As explicated in judicial decisions, bankruptcy judges can thus modify loans on vacation homes, investor properties, multifamily residences in which the owner occupies a unit, and wholly unsecured second mortgages on their principal residences, as well as loans secured by yachts, jewelry, household appliances, furniture or vehicles. The Bankruptcy Code thus prevents modification only of mortgages secured solely by real property that is the debtor's principal residence. Such mortgage loans must be cured and then paid off according to their original terms, including all fees that have been levied since default, or else the bankruptcy automatic stay will be lifted, permitting the mortgagee to foreclose on the property (Levitin 2009). As a result, if a debtor's financial distress stems from an unaffordable home mortgage, bankruptcy is unable to help the debtor retain her home, and foreclosure will occur.

From the enactment of the Bankruptcy Code in 1978, up until mid-1993, some federal courts interpreted the Bankruptcy Code as prohibiting mortgage modification in general but permitting cramdown in particular. That is, a loan could not be modified, but these courts did not see cramdown as modifying the loan. Instead, they understood cramdown to simply be determining the classification of the loan in bankruptcy, namely that under a generally applicable bankruptcy prin- 
cipal, the amount of the claim classified as secured was limited to the value of the collateral. In 1993, however, the Supreme Court ruled on the issue in a case called Nobelman v. American Savings Bank, holding unanimously that cramdown was a form of mortgage modification and therefore prohibited in Chapter 13.

While the Court's ruling was based on statutory interpretation, rather than policy analysis, Justice Steven's concurring opinion emphasized a policy rationale, namely that bankruptcy's special protection for home mortgage lenders is designed to enable lenders to offer lower interest rates and thus encourages home ownership: "At first blush it seems somewhat strange that the Bankruptcy Code should provide less protection to an individual's interest in retaining possession of his or her home than to other assets. The anomaly is, however, explained by the legislative history indicating that favorable treatment of residential mortgagees was intended to encourage the flow of capital into the home lending market. $\left.\right|^{5}$

The implicit model underlying such logic is that the equilibrium interest rate in the market for home loans is determined by the expected return to lenders of such loans. This, in turn, consists of the weighted average of the returns from the loan in various bankruptcy states, where the weights are the probabilities that a given loan ends up in such a state (Berkowitz and Hynes 1999). Cramdown lowers the expected return from a loan should the borrower end up in Chapter 13. This model thus predicts that permitting cramdown should raise interest rates more for those at greatest ex ante risk of filing for bankruptcy under Chapter 13. This varies between loans both because of variation in a borrower's own credit risk and the geographic variation in the use of Chapter 13. We exploit both of these aspects of risk in the analysis below.

\section{The Data}

We collect data for all judicial rulings on the permissibility of cramdown from federal bankruptcy, district and circuit courts between October 1979, the effective date of the Bankruptcy Code, and June 1993, the date of the Supreme Court's decision in Nobelman v. American Savings Bank that cramdown was not permissible under the Code. During this time period, there were roughly 60

\footnotetext{
${ }^{5}$ Nobelman v. American Savings Bank, 508 U.S. 324 (1993).
} 
such rulings in bankruptcy and district courts and four such rulings in circuit courts. Nearly 40 of those lower court rulings and three of the four circuit court rulings held that cramdown was permissible. ${ }^{6}$

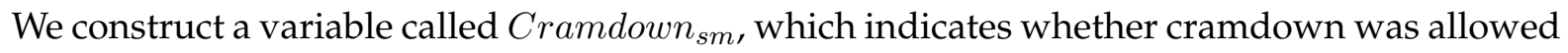
by judicial ruling in state $s$ and month $m$. We assume that prior to any judicial ruling, cramdown was not allowed, in which case Cramdown has value zero. Cramdown has value one in states where all lower courts or a circuit court have ruled in favor of cramdown. In states where only some lower courts have allowed cramdown or where lower courts have conflicting rulings, we assign Cramdown a value equal to the raw average of the permissibility of cramdown across that state's lower courts. For example, Cramdown would have a value of 0.5 in state with one lower court ruling in favor of cramdown and another lower court not having yet ruled on the issue. Though it might be appropriate to construct an average weighted by size of the housing market, such data are difficult to obtain at the federal district level. If using a raw average introduces classical measurement error into our right-hand side variable, our coefficients will be underestimates of the true effect of allowing cramdown.

We collect bankruptcy filing data from the American Bankruptcy Institute, which publishes by state and year the number of bankruptcy filings under each chapter of the Bankruptcy Code. Our main use of such data is to explore whether judicial rulings on cramdown have a larger effect on the mortgage market in states where Chapter 13 bankruptcy filings are more common 7 Using population statistics from the Statistical Abstract of the United States, we assign to each state a measure of Chapter 13 intensity as of 1987, prior to the vast majority of cramdown rulings, which we define as the number of Chapter 13 filings per 1,000 residents in the state.

Our primary outcomes of interest are the cost and quantity of credit in the home loan market. We use the Federal Housing Finance Agency's Monthly Interest Rates Survey (MIRS), which asks mortgage lenders to report the terms on all single-family loans that are closed on the last five business days of each month. The survey excludes multifamily loans, mobile home loans, mort-

\footnotetext{
${ }^{6} \mathrm{~A}$ complete list of these rulings is available from the authors upon request.

${ }^{7}$ We have tried to use this data to estimate the impact of cramdown on bankruptcy filing rates, but the data is available only at the annual level, preventing us from exploiting the precise timing of the judicial rulings that serve as our source of variation. The resulting estimates are too noisy to draw any useful conclusions.
} 
gage refinance loans, loans insured by the Federal Housing Administration and loans guaranteed by the Veterans Administration. MIRS contains information on each loan's interest rate, principal, term, house price, fixed- or adjustable-rate structure, and lender type (savings association, mortgage company, commercial bank, or savings bank).

Table 1 describes the variables from the merged data set in which we assign to each loan in MIRS the value of Cramdown in the state and month that the loan was closed. Because the vast majority of the judicial rulings occurred between 1989 and mid-1993, we limit the sample to loans closed between January 1987 and December 1996, as shown in the first row of the table. The final data set contains over 1.1 million individual loans. The rest of panel (A) shows that, in this time period, $19 \%$ of loans were closed in states and months in which cramdown was allowed by judicial ruling. Circuit rulings covering multiple states account for $13 \%$ of this total while lower court rulings account for $6 \%$ of the total. The final row of the panel shows that the average loan was issued in a state that, in 1987, had a Chapter 13 filing rate of 0.5 per 1,000 residents. This rate varied widely between states, with a minimum of 0.01 (in Vermont) and a maximum of 2.76 (in Tennessee).

Panel (B) shows some of the outcomes of interest in this paper, namely the measures of the quantity and price of credit. The average principal of a loan in the MIRS data over this time period was $\$ 112,000$, with an average loan-to-value ratio of $77 \% 8$ The effective interest rate, which is the stated interest rate on the loan plus the implied interest cost of any fees associated with the loan, averaged $8.22 \% 9$ Panel $(\mathrm{C})$ shows other characteristics of these loans, including average term (nearly 28 years), the fraction that have adjustable rates (42\%), and the types of lenders (64\% are traditional savings banks and $27 \%$ are mortgage companies).

\footnotetext{
${ }^{8}$ This measures the ratio of the loan principal to the price of the home.

${ }^{9}$ We focus on the effective interest rate rather than the stated interest rate because lenders could potentially compensate for cramdown risks by increasing up front fees rather than the interest rate. In practice, the difference between these two quantities is small, on the order of 20 basis points on average. Our results are unaffected by the choice of which interest rate measure to use.
} 


\section{Empirical Strategy}

Figure 1 shows two different measures of the extent to which the various judicial rulings on cramdown changed the legal environment. The panel (A) shows the fraction of states in a given month in which at least one judicial decision allowing cramdown was in force. At the start of this time period, in January 1987, only a handful of states had experienced such rulings. That number rose relatively slowly until October 1989, when the Ninth Circuit issued a ruling allowing cramdown in Hougland v. Lomas \& Nettleton Co. The fraction of states with such rulings then continued a fairly steady climb until the issue reached the Supreme Court, which in June 1993 ruled in Nobelman $v$. American Savings Bank that the Bankruptcy Code should not be interpreted to allow cramdown under Chapter 13. That ruling disallowed cramdown in all states. Panel (B) shows the fraction of loans in our data issued under cramdown-allowing judicial regimes. This panel can be thought of as a version of panel (A) in which each state is weighted by the number of loans issued in that state and month. The sharp rise in October 1989 highlights the large fraction of the home loan market covered by the Ninth Circuit decision, relative to the decisions of smaller jurisdictions at other times. Figure 1 shows that, by early 1993, judicial rulings allowing cramdown applied to over 30 states and covered about $60 \%$ of the home loans issued in the United States.

Both panels highlight a simple way to think of this natural experiment. At the start of this time period, cramdown was allowed in very few jurisdictions. Between 1989 and 1993, cramdown became legal in a large number of jurisdictions. Then, in June 1993, the Supreme Court returned the US to its prior state, in which cramdown was not allowed anywhere. The natural experiment is thus driven by the fact that, for a 3-4 year window, cramdown was unexpectedly made legal in some jurisdictions but not in others. This fact suggests the use of a difference-in-difference strategy estimating whether the differences in home loan conditions between cramdown-allowing states and cramdown-forbidding states was different in the period when cramdown was allowed relative to the periods before and after.

We employ this strategy, but augment it by exploiting a few further facts highlighted in Figure

2. First, as seen in panel (A), states differed not only according to whether cramdown was ever allowed by judicial ruling but also in the timing of such rulings. Six states had rulings allowing 
cramdown as early as 1987-88, while the remaining states are relatively evenly split between first rulings in 1989-90, first rulings in 1991-92, and never having rulings allowing cramdown. This differential timing provides an additional source of variation that we exploit in our subsequent regression analysis, allowing us to separate the effect of the judicial rulings from other contemporaneous factors affecting the nation as a whole. Panels (B) and (C) highlight two further sources of heterogeneity we explore. Panel (B) reveals that, in addition to the differential timing of judicial rulings, the highest level of cramdown ruling also varied by state, with some states subject only to lower court rulings and other eventually subject to circuit court rulings. Given that lower court rulings can be overturned by circuit courts, we might expect markets to react more strongly to circuit court rulings that have a higher likelihood of becoming a permanent feature of the legal environment. We explore this hypothesis in the subsequent analysis.

We also explore in the subsequent analysis the extent to which the bankruptcy environment interacts with these judicial rulings. As panel (C) shows, there is geographic variation in the extent to which residents of a given state file for bankruptcy under Chapter 13, with such filings more common in the South and West. We might expect markets to react more strongly to judicial rulings allowing cramdown in states where Chapter 13 filings are more common. In these states, lenders might expect lower returns on loans because of the higher probability that loans would end up in Chapter 13 and thus potentially being crammed down.

We thus exploit the facts that states differed both in the extent to which cramdown was ever allowed and the timing of such rulings. We do so by implementing difference-in-difference regressions of the form:

$$
Y_{l s m}=\beta_{0}+\beta_{1} \text { Cramdown }_{s m}+\mu_{s}+\lambda_{m}+X_{l s m}+\epsilon_{l s m}
$$

Here $Y$ is a characteristic, such as an interest rate or principal amount, of loan $l$ closed in state $s$ in month $m$. The variable Cramdown measures the extent to which cramdown is allowed in that state and month, as defined previously. State fixed effects $\mu$ control for any differences between states that are constant across time, such as differing provisions in state bankruptcy laws. Month fixed effects $\lambda$ control for any differences between months that are constant across states, such as 
shocks to the national economy or interest rate changes by the Federal Reserve. We control in some specifications for $X$, a vector of loan characteristics including the loan's term, its loan-tovalue ratio, an indicator for adjustable rate, and indicators for each type of lender.

The inclusion of state and month fixed effects means that $\beta_{1}$, the coefficient of interest, is identified by within-state changes in the legal status of cramdown, controlling for monthly nationwide shocks. This means that the observed correlations between cramdown rulings and loan conditions such as interest rates cannot be caused by differences across states with differing cramdown rulings or by correlations between the timing of rulings and nationwide shocks.

For certain outcomes, we run versions of the above regression in which we collapse the data to state-month cells by mean or various percentiles:

$$
Y_{s m}=\beta_{0}+\beta_{1} \text { Cramdown }_{s m}+\mu_{s}+\lambda_{m}+\epsilon_{s m}
$$

In all specifications, the error term $\epsilon$ may have an unobserved component correlated within states across time, so we cluster the standard errors at the state level to account for such serial correlation.

\section{Empirical Results}

Table 2 shows the mean impact of cramdown rulings on the equilibrium quantity and price of home loans. Columns (1)-(4) use as outcomes four different measures of the quantity of credit transacted in a given market. Columns (1) and (2) collapse the data to state-month cells. In column (1), the outcome is the logarithm of the number of loans closed in a given state and month. In column (2), the outcome is the logarithm of the total amount of principal loaned in a given state and month. In panel (A), the point estimates in those two columns suggest that cramdown is associated with a roughly one percent decrease in the quantity of loans and loaned funds, but the standard errors render the estimates very imprecise. Columns (3) and (4) use as outcomes the logarithm of each loan's principal amount and loan-to-value ratio. The standard errors on the two coefficients in panel (A) are still too large to reject the hypothesis that loan quantities are unaffected by the judicial rulings. Overall, these four columns provide little evidence of an impact 
of cramdown rulings on the quantity of loans transacted in these markets.

In columns (5)-(8), we explore the impact of cramdown rulings on the price of credit as measured by the effective interest rate on these home loans. In column (5), which controls only for state and month fixed effects, the coefficient implies that the cramdown rulings led to a statistically significant rise in the interest rate of 12 basis points. Column (6) shows that this estimate is unchanged by the inclusion of state-specific linear time trends and state-level monthly unemployment rates, suggesting that cramdown rulings are not more likely in states with a prior interest rate trajectory nor are correlated in time with local economic conditions. In column (7), the estimated impact of allowing cramdown rises slightly to 14 basis points when we control for loan characteristics such as term, loan-to-value ratio, adjustable rate status, and lender type. Finally, in column (8), we exclude from the sample the subset of states in which no judicial ruling in this period ever permitted cramdown, on the theory that such states may differ fundamentally from states with such rulings and thus might not be ideal controls. This exclusion raises the estimated impact of allowing cramdown to 16 basis points. These robust results provide clear evidence that such rulings led to a rise in the cost of credit, on the order of 12-16 basis points.

Panel (B) interacts the cramdown measure with indicators for whether the highest ruling in a given month came from a circuit court or a lower court. There is no clear evidence in the first four columns of an impact of either type of decision on loan quantities. The last four columns reveal, however, that the interest rate increase seen in panel (A) is driven entirely by the circuit court rulings on cramdown, with point estimates on such rulings ranging from 14-19 basis points. This is consistent with the theory that lenders in a given jurisdiction believe circuit court decisions to be much better predictors of the actual future state of the law than lower court decisions, which are overturned with some frequency. In other words, lower court rulings had much less impact than circuit court rulings on lenders' beliefs about the expected returns to newly issued loans.

As discussed earlier, cramdown permissibility should theoretically have the largest impact on loans at greatest risk of default. The MIRS data have no good proxy for risk, such as a credit score, so we instead explore the impact of cramdown on the full distribution of interest rates within a state in a given month. We assume that, in a given state and month, the loans with the 
highest interest rates are on average those judged by lenders to be the riskiest. Loans with low interest rates, conversely, are those made to borrowers with high credit scores and thus little risk of default. We would therefore expect cramdown permissibility to have relatively small impacts on loans with low interest rates and relatively big impacts on loans with high interest rates.

Panel (A) of Table 3 confirms this prediction. Here we have collapsed the loan data to statemonth cells, computing the mean and 10th through 90th percentiles of that distribution. We then run regressions with state and month fixed effects as before, but weight the regressions by the number of loans in each cell. Column (1) thus replicates our central result from column (5) of Table 2, showing that the mean impact of cramdown is a 12 basis point rise in interest rates. The remaining columns show no impact of cramdown on the 10th through 40th percentile of the interest rate distribution, loans likely made to the least risky borrowers. Higher percentiles of the interest rate distribution are, however, affected by cramdown rulings, with the 60th through 90th percentiles seeing interest rate increases of 21-35 basis points. This is consistent with the prediction that bankruptcy regulations affect credit markets for those most at risk of defaulting on loan obligations.

Because cramdown only affects those who file for bankruptcy under Chapter 13, theory also predicts that cramdown permissibility should have a larger impact in states where Chapter 13 is more commonly used. In panel (B) of Table 3, we interact cramdown permissibility with a demeaned measure of the Chapter 13 filing rate per thousand residents in 1987, prior to these rulings. The empirical results are consistent with the theoretical prediction. The coefficients on the interaction term are noisy zeroes for the least risky loans but become consistently positive and significant for loans at and above the 70th percentile of the distribution. This implies that, for the riskiest borrowers, cramdown permissibility raises interest rates more in states with higher Chapter 13 filing rates. Taken together, these two panels show consistent evidence that changes in bankruptcy regulations have the largest impact on risky borrowers in jurisdictions where the relevant form of bankruptcy is a likely outcome. 


\section{Discussion and Conclusion}

Using state- and month-level variation in judicial rulings as a source of exogenous variation in policy, we find that giving judges the power to modify home loans through principal reductions does, as theory predicts, raise the cost of credit. This provides some of the clearest evidence to date of the impact of bankruptcy law on credit markets.

Our point estimates suggest that, during this time period, the permissibility of cramdown raised interest rates on home loans by an average of 10-20 basis points, which translates into a 1$2 \%$ increase in monthly payments. This relatively small impact may be explained by three factors. First, if losses in foreclosure would be high, cramdown may have little ultimate effect on a lender's recovery. Second, Chapter 13 bankruptcy filings were relatively uncommon during the period in question, peaking at $0.6 \%$ of all residential mortgages, so that Chapter 13 cramdown would have been a comparatively rare occurrence 10 Third, the majority of Chapter 13 filings do not result in a completed repayment plan, so that lenders often end up foreclosing on the properties anyway (Porter 2011). Therefore, even if cramdown were legally possible, the result in most bankruptcy cases would often be the same as would occur outside of bankruptcy, except to the extent that judicial valuation varies from market valuation.

Extrapolating from our results to current policy may therefore be challenging. Whether current attempts to legalize cramdown would result in similarly small impacts on interest rates depends on how current conditions differ from those in the 1980s and 1990s. On the one hand, the depressed macroeconomy drove the number of Chapter 13 filings in 2010 to nearly 440,000, 75\% higher than the 1992 peak cited previously, which suggests that cramdown might have even larger impacts on lenders' behavior than it did in the period we have studied. Moreover, were cramdown available, Chapter 13 bankruptcy filing would be more attractive to homeowners, which could increase filing rates. On the other hand, the depressed state of the housing market means that foreclosure losses might also be quite high, so principal modification might result in smaller

\footnotetext{
${ }^{10}$ During the period examined, annual Chapter 13 filings peaked at about 254,000 in 1992 (U.S. Courts Historical Statistics). The Census's 1993 American Housing Survey lists 37.2 million mortgaged properties (Table 3-15). Furthermore, not all such filings involved homeowners with mortgages, and only some home mortgagors filing for Chapter 13 were both underwater and in judicial districts that permitted cramdown.
} 
losses to lenders if the modified loans perform.

The one clear finding of ours that would certainly translate to the current environment is the heterogeneous impact of bankruptcy law generally and cramdown specifically on borrowers with differing credit risks. Our results suggest strongly that cramdown has little impact on the credit market for those at low risk ending up both underwater and in bankruptcy. The riskiest borrowers bear the full cost of the change in legal regime. As such, legislation permitting principal modification by bankruptcy judges can be thought of as a form of insurance against foreclosure. Though such insurance would be mandatory, in the sense that all borrowers are subject to the same legal regime in bankruptcy, our evidence shows that only the riskiest borrowers would ultimately pay for the privilege of such insurance. In this sense, cramdown may even be efficiency-enhancing by creating a form of insurance that the private market does not provide. 


\section{References}

Berkowitz, J. and R. Hynes (1999). Bankruptcy exemptions and the market for mortgage loans. Journal of Law and Economics 42(2), 809-830.

Berkowitz, J. and M. White (2004). Bankruptcy and small firms' access to credit. RAND Journal of Economics 35(1), 69-84.

Braucher, J., D. Cohen, and R. M. Lawless (2012). Race, attorney influence, and bankruptcy chapter choice. Journal of Empirical Legal Studies 9(3), 393-429.

Case, K. E., J. M. Quigley, and R. J. Shiller (2011). Wealth effects revisited 1978-2009. Working Paper 16848, National Bureau of Economic Research.

Chomsisengphet, S. and R. Elul (2006). Bankruptcy exemptions, credit history, and the mortgage market. Journal of Urban Economics 59(1), 171-188.

Dynan, K. (2012). Is a household debt overhang holding back consumption? Working paper, Brookings Institution.

Fitzpatrick IV, T. and J. Thomson (2010). Stripdown and bankruptcy: lessons from agricultural bankruptcy reform. Technical Report 2010-9, FRB of Cleveland.

Gelpern, A. and A. Levitin (2009). Rewriting Frankenstein contracts: Workout prohibitions in residential mortgage-backed securities. Southern California Legal Review 82, 1077-1152.

Gropp, R., J. Scholz, and M. White (1997). Personal bankruptcy and credit supply and demand. The Quarterly Journal of Economics 112(1), 217-251.

Jimenez, D. (2009). The distribution of assets in consumer Chapter 7 bankruptcy cases. American Bankruptcy Law Journal 83, 795-822.

Levitin, A. (2009). Resolving the foreclosure crisis: Modification of mortgages in bankruptcy. Wisconsin Law Review 2009(1), 565-656.

Levitin, A. (2010). Bankruptcy markets: Making sense of claims trading. Brooklyn Journal of Corporate, Financial \& Commercial Law 4(1), 64-109.

Levitin, A. and T. Twomey (2011). Mortgage servicing. Yale Journal on Regulation 28(1), 1-90.

Lin, E. and M. White (2001). Bankruptcy and the market for mortgage and home improvement loans. Journal of Urban Economics 50(1), 138-162.

Luzzetti, M. and S. Neumuller (2012). Bankruptcy reform and the housing crisis. Technical report, UCLA.

Mayer, C., K. Pence, and S. Sherlund (2009). The rise in mortgage defaults. Journal of Economic Perspectives 23(1), 27-50.

Pence, K. (2006). Foreclosing on opportunity: State laws and mortgage credit. Review of Economics and Statistics 88(1), 177-182. 
Porter, K. (2011). The pretend solution: An empirical study of bankruptcy outcomes. Texas Law Review 90(1), 103-162.

White, M. (2011). Corporate and personal bankruptcy law. Technical Report 17237, National Bureau of Economic Research. 
Figure 1: Timing of Cramdown Rulings

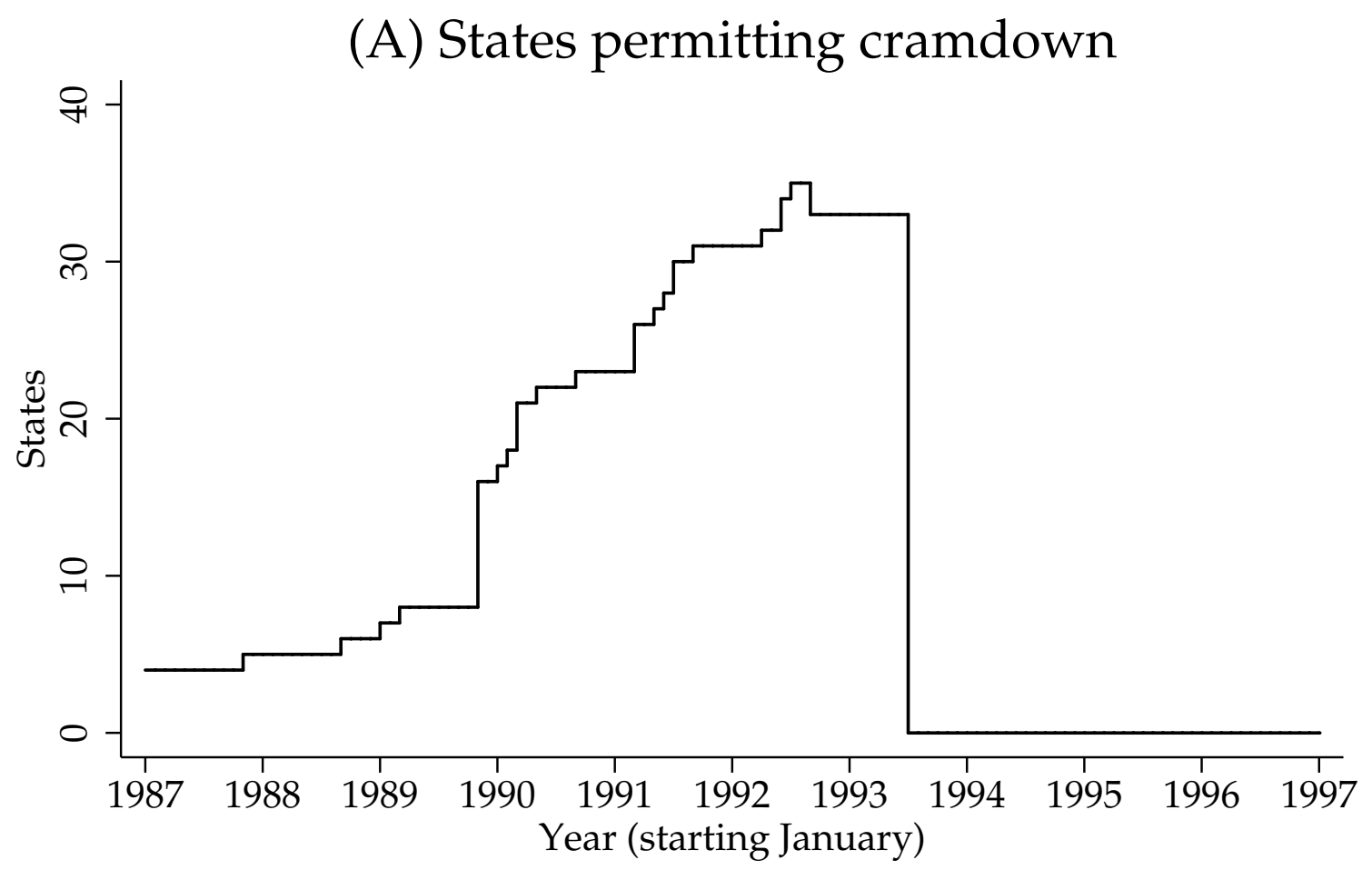

(B) Loans subject to cramdown

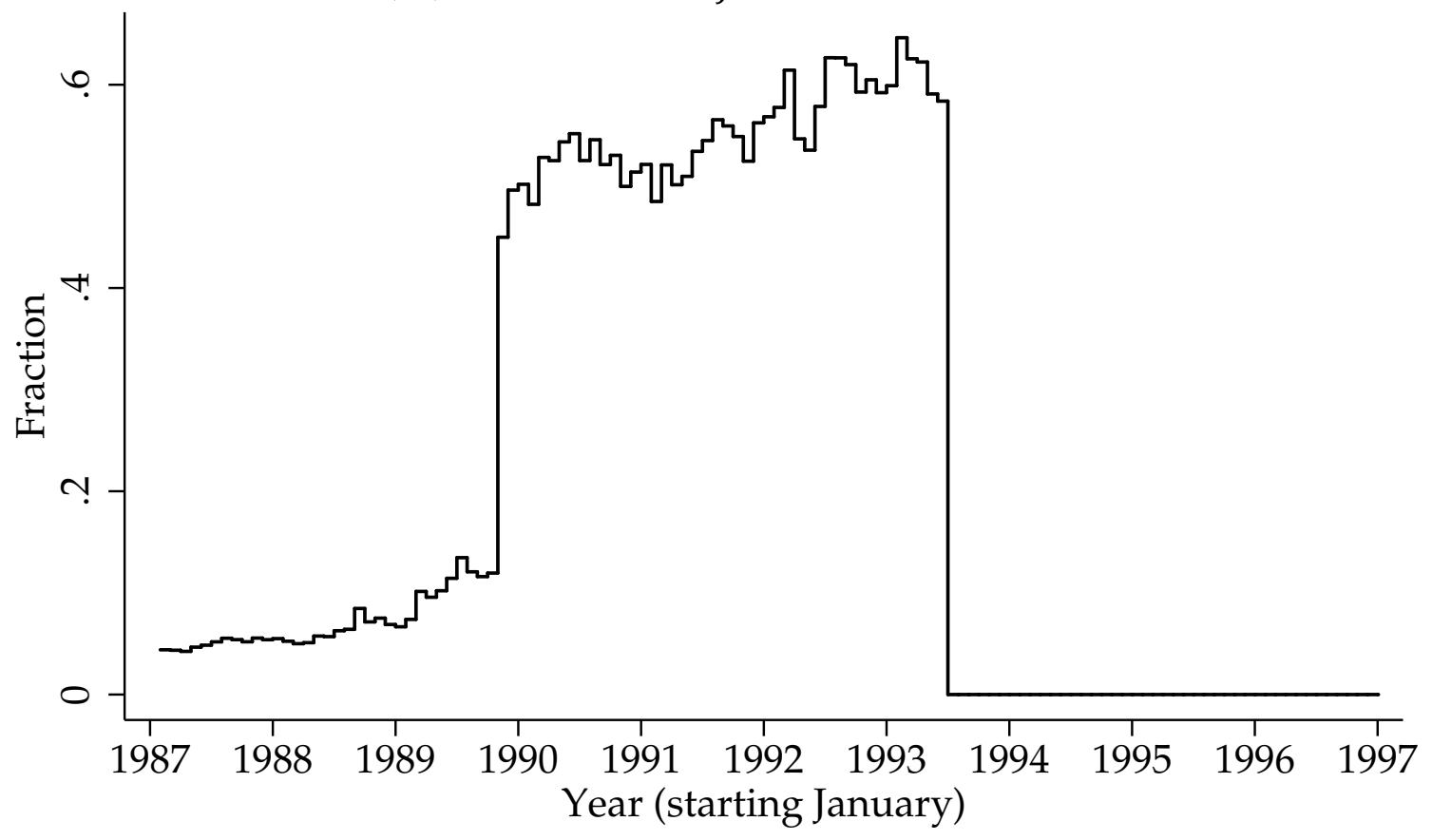


Figure 2: Geography of Cramdown Rulings

(A) First year cramdown allowed in state

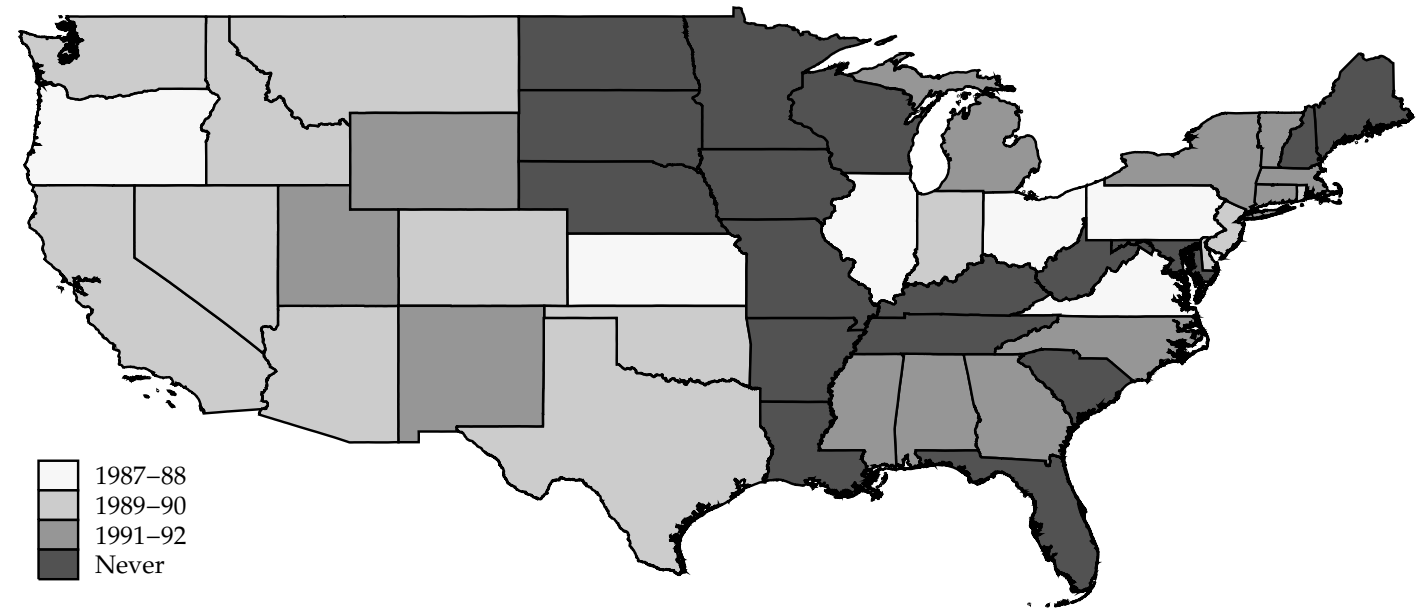

(B) Highest level of cramdown ruling

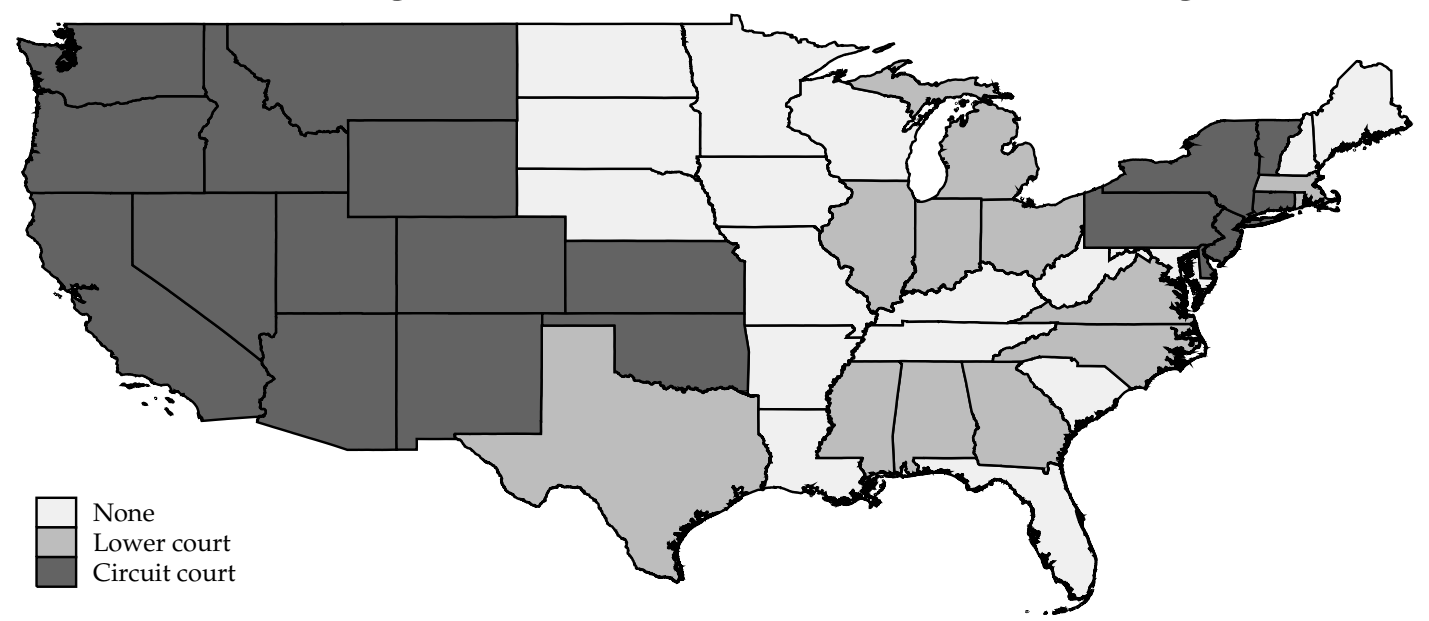

(C) Ch. 13 filings per 1000 residents

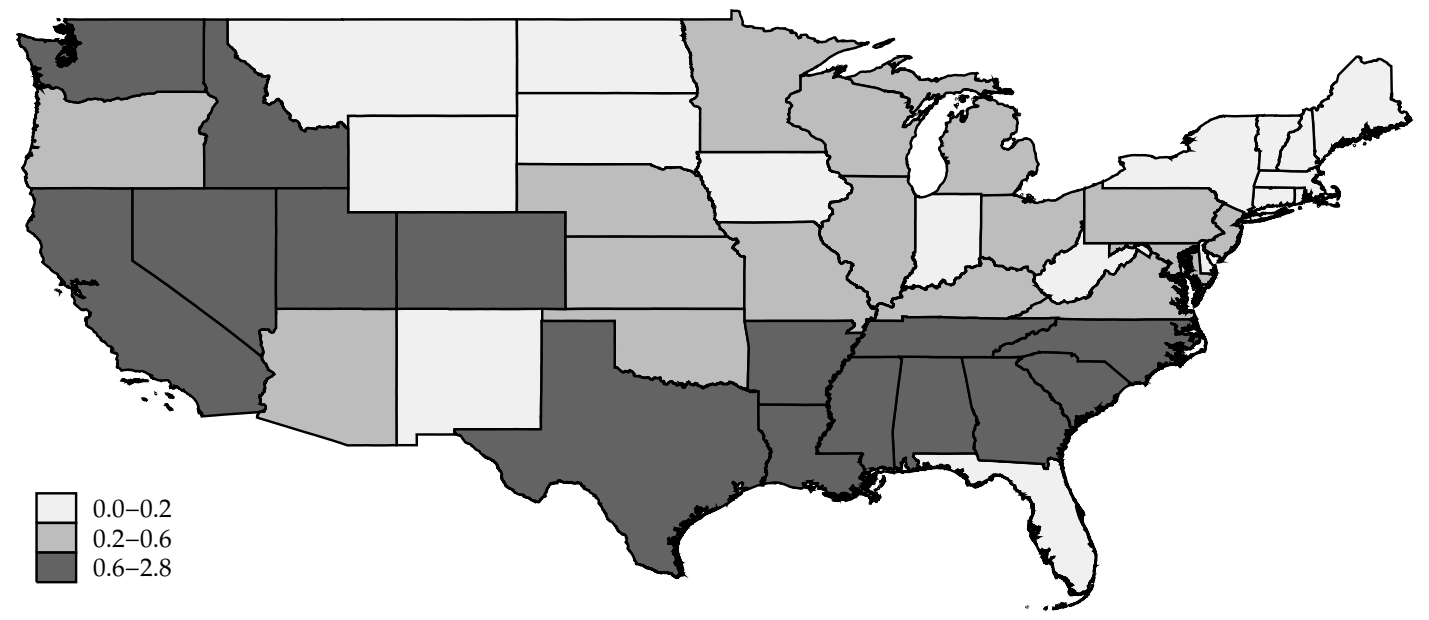


Table 1: Summary Statistics

(1)

Mean

(A) Cramdown

Months since January 1, 1987

Cramdown allowed

Allowed by circuit court

Allowed by lower court

Chapter 13 filing rate (1987)

(B) Loan quantity and price

Loan principal ('000s)

Loan-to-value

Effective interest rate

(C) Other loan characteristics

Term of loan (years)

Adjustable rate

Savings banks

Mortgage company

Commerical bank

FDIC thrift
65.17

0.19

0.13

0.06

0.50

112.04

0.77

8.22

27.77

0.42

0.64

0.27

0.05

0.04
(2) St. dev.

(3)

Minimum

Maximum

35.23

0.36

0.33

0.18

0.39

68.35

0.15

1.53

6.37

0.49

0.48

0.45

0.21

0.20
1.00

0.00

0.00

0.00

0.01

3.00

0.03

2.75

1.00

0.00

0.00

0.00

0.00

0.00
120.00

1.00

1.00

1.00

2.76

725.12

1.25

23.59

50.00

1.00

1.00

1.00

1.00

1.00

Notes: Sample size is 1,145,277 loans. Chapter 13 filing rate measures filings per 1,000 residents in 1987 for each state. Principal is measured in thousands of current dollars. The loan-to-value measures the ratio of principal to home price. The effective interest rate is the stated interest rate plus the implied interest cost of any fees associated with the loan. Savings banks refers to federal- and state-chartered savings banks and savings and loans associations regulated by the Office of Thrift Supervision. 


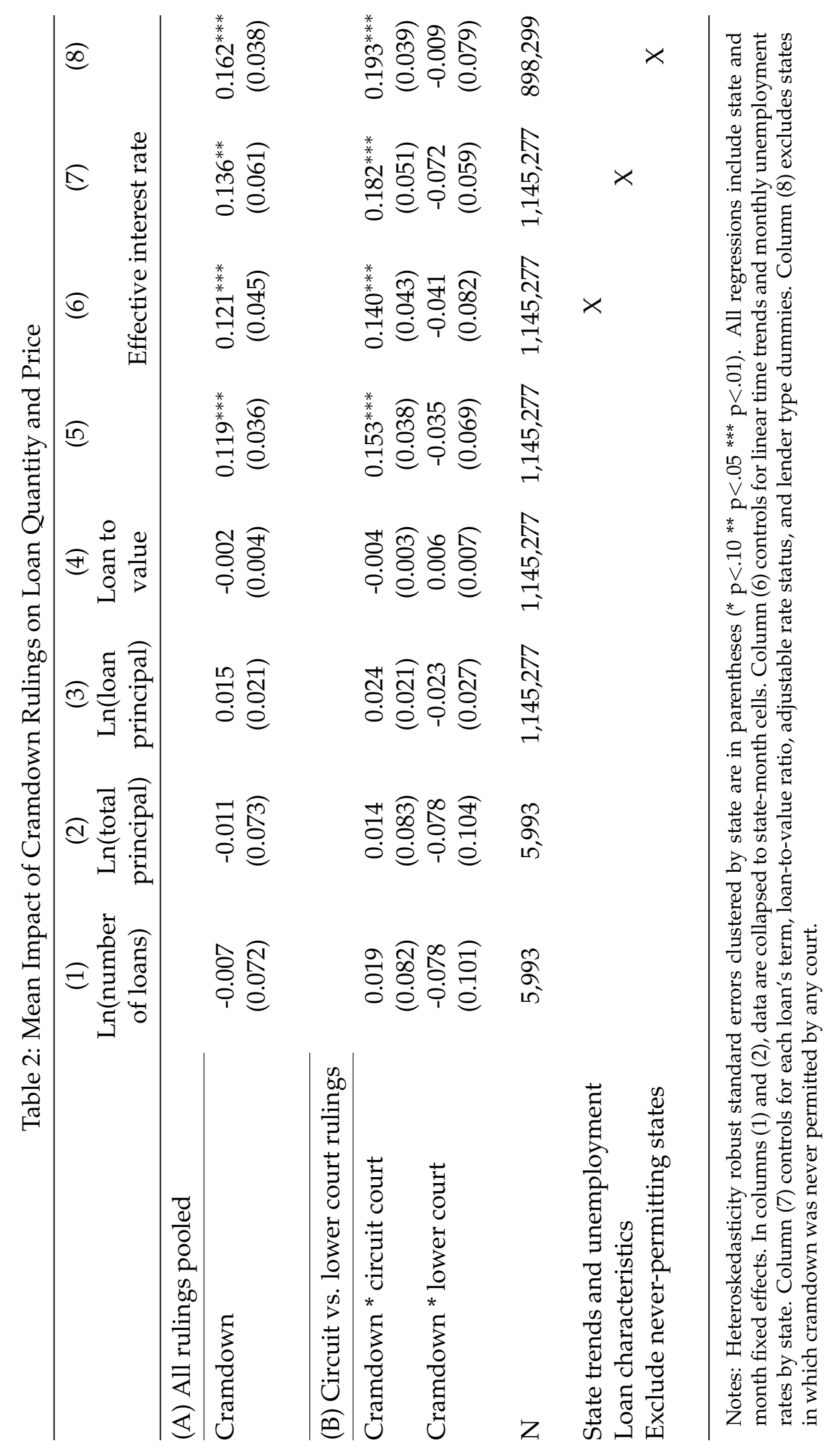




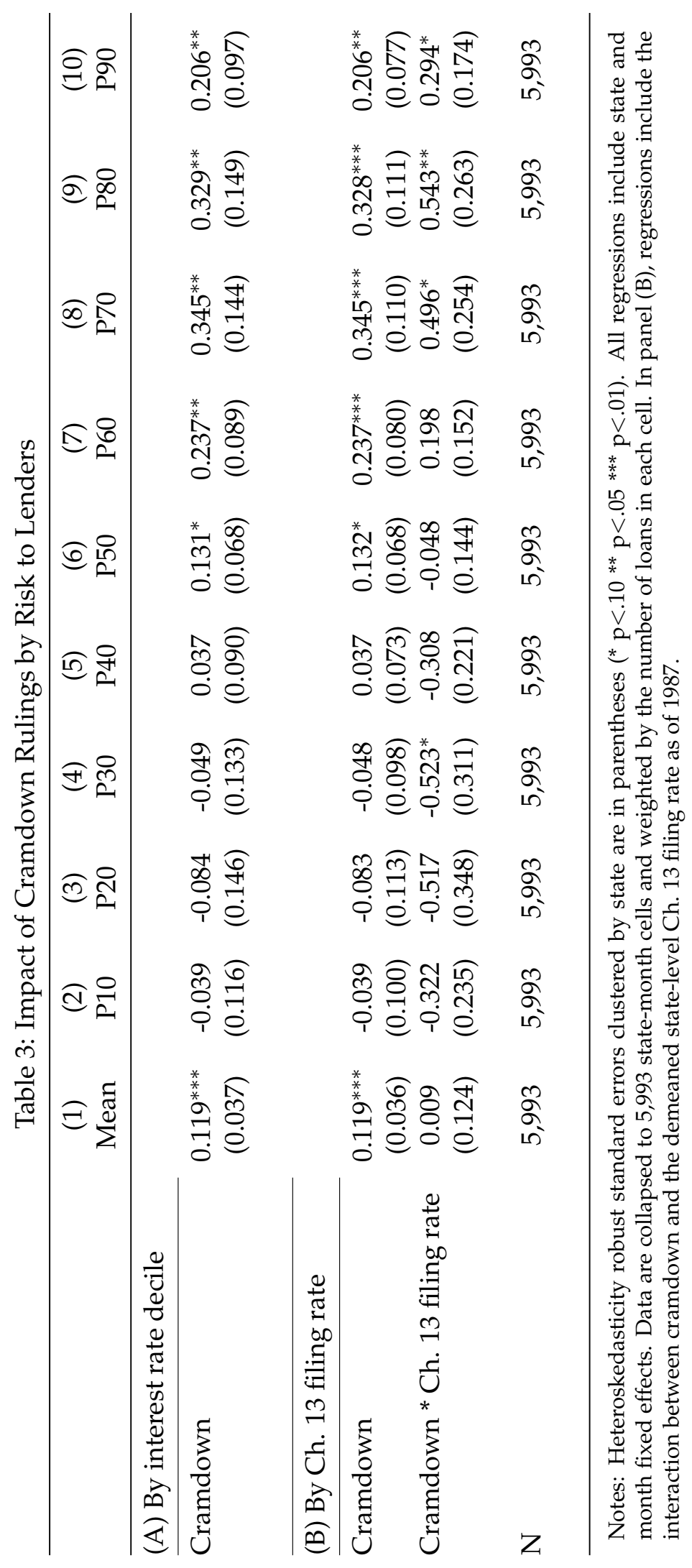

